\title{
Sistem Proteksi Pelepasan Beban dengan Metode Descending Menggunakan Macro VBA
}

\author{
Muhammad Fajar1), Herfia Rhomadhona $^{2)}$, Khairul Anwar Hafizd ${ }^{3)}$ \\ ${ }^{122) 3)}$ Program Studi Teknik Informatika, Politeknik Negeri Tanah Laut \\ Jalan Ahmad Yani Km. 06 Desa Panggung Kalimantan Selatan 70815, Pelaihari \\ 1) muhammadfajarit19@gmail.com \\ ${ }^{2)}$ herfia.rhomadhona@politala.ac.id \\ ${ }^{3)}$ khairul.anwarhafizd@gmail.com
}

\begin{abstract}
Abstrak
Beberapa bulan terakhir ini, PT. PLN WKSKT melakukan pemadaman secara sengaja untuk mencegah kegagalan jaringan sistem pembangkit. Pemadaman tersebut terjadi karena terdapat penggunaan beban yang tidak merata. Penggunaan beban terbesar saat ini, berada pada skema line transmisi Barikin arah Tanjung dan Barikin arah Cempaka. Kedua skema tersebut merupakan kondisi beban krusial saat terjadi gangguan pada line transmisi. Hal itu dapat mengganggu transmisi beban pada target yang berada didalam kedua skema tersebut sehingga menyebabkan padam listrik (trip) dan padam total wilayah (blackout). Untuk mengatasi masalah tersebut, PT. PLN WKSKT membuat skema khusus untuk sistem proteksi beban pada target tertentu. Yang mana sistem tersebut mampu mengurutkan beban target dari yang besar hingga kecil. Descending merupakan metode pengurutan yang dapat menyelesaikan tujuan sistem proteksi. Dengan metode tersebut beban target diurutkan dan kemudian dikalkulasi pada macro VBA. Target beban yang telah diurutkan kemudian dijumlah hingga setara dengan transfer line. Kalkulasi yang dilakukan pada macro VBA bertujuan untuk mendapatkan status melepas beban dengan indikasi enable, ready dan trip (padam listrik). Ketiga indikasi tersebut digunakan untuk memonitoring kondisi beban secara real time. Sehingga sistem proteksi mampu menghindari gangguan yang dapat menyebabkan black out pada sistem kelistrikan.
\end{abstract}

Kata kunci: sistem proteksi, pelepasan beban, metode descending, macro VBA

\begin{abstract}
The last few months, PT. PLN WKSKT deliberately goes out to prevent the failure of the generator system network. Blackouts occur because there are uneven load uses. The use of the largest load is in the Barikin transmission line scheme towards the Tanjung and Cempaka direction. Both schemes are crucial load conditions when there is a disruption in the transmission line. This can interfere with the transmission of the load on targets that are in the two schemes, cause trips and blackouts. To resolve the issue, PT. PLN WKSKT create a special scheme for the protection system loads on specific targets. Which system can sort the target load from large to small. Descending is a sorting method that can complete the purpose of a protection system. With this method the target load is sorted and then calculated in VBA macros. The target load that has been sorted is then added to the equivalent of the line transfer. Calculations performed on VBA macros aim to obtain load release status based on enable, ready and trip indications. All three indicators used to monitor the load condition real time. So that the protection system is able to avoid interference that can cause black out on the electrical system
\end{abstract}

Keywords: protection system, load release, descending method, VBA macros 


\section{PENDAHULUAN}

PT. PLN (Persero) UP3B Sistem Kalimantan Selatan dan Kalimantan Tengah merupakan Unit Pelaksana Pengatur dan Penyalur Beban (UP3B) yang berada diwilayah Kalimantan Selatan dan Kalimantan Tengah. UP3B merupakan unit yang bertugas dalam mengatur beban yang disalurkan kepada pelanggan se-Kalimantan Selatan dan Kalimantan Tengah. Kegiatan UP3B dikelola oleh SCADA (Supervisory Control and Data Acquisition). SCADA disebut sebagai bidang yang me-remote sistem tenaga listrik yang berada di gardu induk. Sistem remote juga mengamankan sistem tenaga listrik yang terpasang dari gangguan listrik atau beban berlebih (overload), dengan cara memisahkan bagian sistem tenaga listrik yang terganggu dengan sistem tenaga listrik yang tidak terganggu, sehingga sistem kelistrikan yang tidak terganggu dapat terus bekerja (mengalirkan arus beban).

Penggunaan beban terbesar saat ini, berada di skema line transmisi Barikin arah Tanjung dan Barikin arah Cempaka. Kedua skema tersebut merupakan kondisi beban krusial terjadi gangguan pada line transmisi karena mengganggu transmisi beban pada target yang berada didalam kedua skema. sehingga menyebabkan padam listrik dan padam total wilayah pada jalur transmisi kedua skema tersebut. Untuk itu, dibutuhkan sebuah metode yang dapat mengurutkan beban target dari yang besar hingga kecil.

Metode descending merupakan pengurutan data secara menurun yakni dengan memperhitungkan beban target dari yang paling besar hingga paling kecil. Dengan metode tersebut beban target diurutkan dan kemudian dikalkulasi di macro VBA. Target beban diurutkan menurun dari beban terbesar hingga beban terkecil lalu dijumlah hingga setara dengan transfer line, pada saat terjadi gangguan pada transfer line, target beban dilepaskan sesuai dengan transfer line pada saat itu. Kalkulasi dilakukan pada macro VBA untuk mendapatkan status melepas beban dengan indikasi enable serta penerima sinyal ready melepas beban pada mini-pc (raspberry) yang ditempatkan pada setiap panel gardu induk.

Dengan sistem proteksi seperti itu diharapkan pelepasan beban terjadi secara dinamis menyesuaikan kondisi beban secara real-time. Agar melindungi kinerja kelistrikan dan pembangkit dengan cara melepas beban sesuai dengan skema transfer line yang telah ditentukan sehingga mampu menghindari gangguan meluas yang dapat menyebabkan black out pada sistem kelistrikan. Sistem proteksi dapat dimonitorng melalui halaman browser dengan tool NodeRED.

\section{TINJAUAN PUSTAKA}

\subsection{Sistem Proteksi}

Sistem Proteksi merupakan perlindungan terhadap komponen tenaga listrik saat terjadi gangguan pada komponen tenaga listrik (Shan, Zhao, Zhang, Guan, \& Liu, 2009).

\subsection{Metode Descending}

Descending merupakan pengurutan suatu data berdasarkan data yang paling besar hingga data paling kecil atau proses pengurutan data secara menurun (Mohammed, Amrahov, \& Çelebi, 2017).

\subsection{Macro VBA}

Macro VBA atau Visual Basic for Application merupakan fitur dalam Microsoft yang berfungsi sebagai penunjang dalam membangun sebuah program berisi baris perintah kode program (Hongsheng, 2010).

\subsection{Node-RED}

Node-RED merupakan sebuah tool berbasis web yang digunakan untuk membangun aplikasi IoT. Seperti namanya cara penggunaan Node-RED cukup mudah dengan melakukan drag and drop potongan Node, karena setiap potongan Node berisi kode program sehingga pengguna tidak banyak dalam penuangan kode dalam membangun sebuah program aplikasi (Mulyono, Qomaruddin, \& Anwar, 2018). 


\section{METODE PENELITIAN}

Gambar 1 merupakan alur atau tahapan yang telah dilakukan pada penelitian ini. Penelitian ini dilaksanakan di Kantor SCADA UP3B PT. PLN Persero Wilayah Kalimantan Selatan dan Kalimantan Tengah.

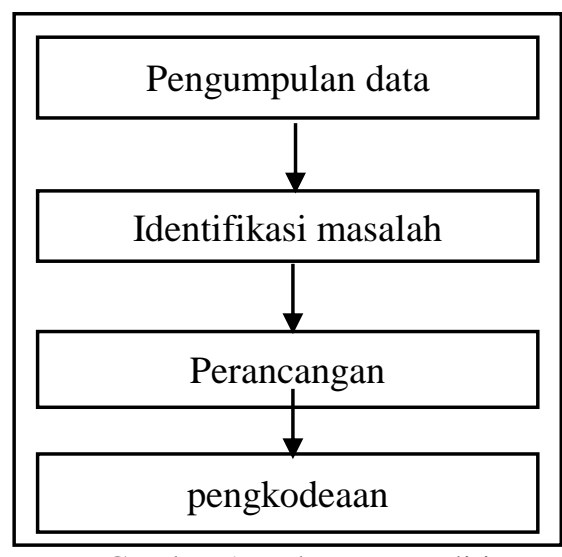

Gambar 1. Tahapan penelitian

\section{a. Pengumpulan data}

Pengumpulan data pada penelitian yaitu teknik wawancara dan teknik observasi. Metode wawancara ini dilakukan dengan cara tanya jawab secara langsung dengan pembimbing lapangan dan karyawan yang berhubungan dengan kasus Special Protection Scheme. Sedangkan Metode observasi dilakukan dengan melakukan pengamatan secara langsung mengenai kasus yang dibahas dan pembuatan panel yang dibimbing langsung oleh karyawan perusahaan.

b. Identifikasi masalah

Tahap analisis kebutuhan perangkat lunak adalah proses pengumpulan data yang dilakukan penulis dimulai dengan meng-import data dari database Oracle ke Excel menggunakan tns.ora agar terhubung database Oracle ke Excel, data yang diimport adalah data Teknikal Address (TA) lalu difilter menjadi dua bagian yakni scheme1 dan scheme2, data yang sudah difilter menjadi scheme1 dan scheme2 disebut dengan data Target.

\section{c. Perancangan}

Tahap desain merupakan tahap merancang perangkat Special Protection Scheme mulai dari alur kerja perangkat, tampilan hingga custome panel yang akan dibangun. Desain struktur database perangkat Spesial Protection Scheme ini menggunakan Flowchart dan untuk tampilan antarmuka menggunakan tool NodeRED.

\section{d. Pengkodean}

Tahap pengkodean ini merupakan tahap penuangan kode program dan komentar sehingga mempermudah fungsi setiap baris kode. Pada tahap ini penulis menggunakan Bahasa pemrograman Macro VBA (Visual Basic for Application)

\section{PEMBAHASAN}

Sistem Special Protection Scheme ini dimulai dari akusisi SCADA yang disimpan pada database MySQL, kemudian data dikalkulasi pada macro VBA dengan diisi target dari yang paling besar hingga beban mendekati atau setara dengan transfer line. Apabila data tidak sesuai maka program akan mengulang kalkulasi hingga beban mendekati atau setara dengan nilai transfer line. Setelah itu sistem di update rate setiap 10 detik, kemudian update lojik pada target akan bernilai enable $=$ ON jika target termasuk dalam kuota OLS (On Load Shedding) dan bernilai ready pada Raspberry PI. Sehingga program siap melepas beban mengalami penuruan frekuensi hingga $49.5 \mathrm{~Hz}$. 
Berikut flowchart SPS dapat dilihat pada gambar 2 berikut.

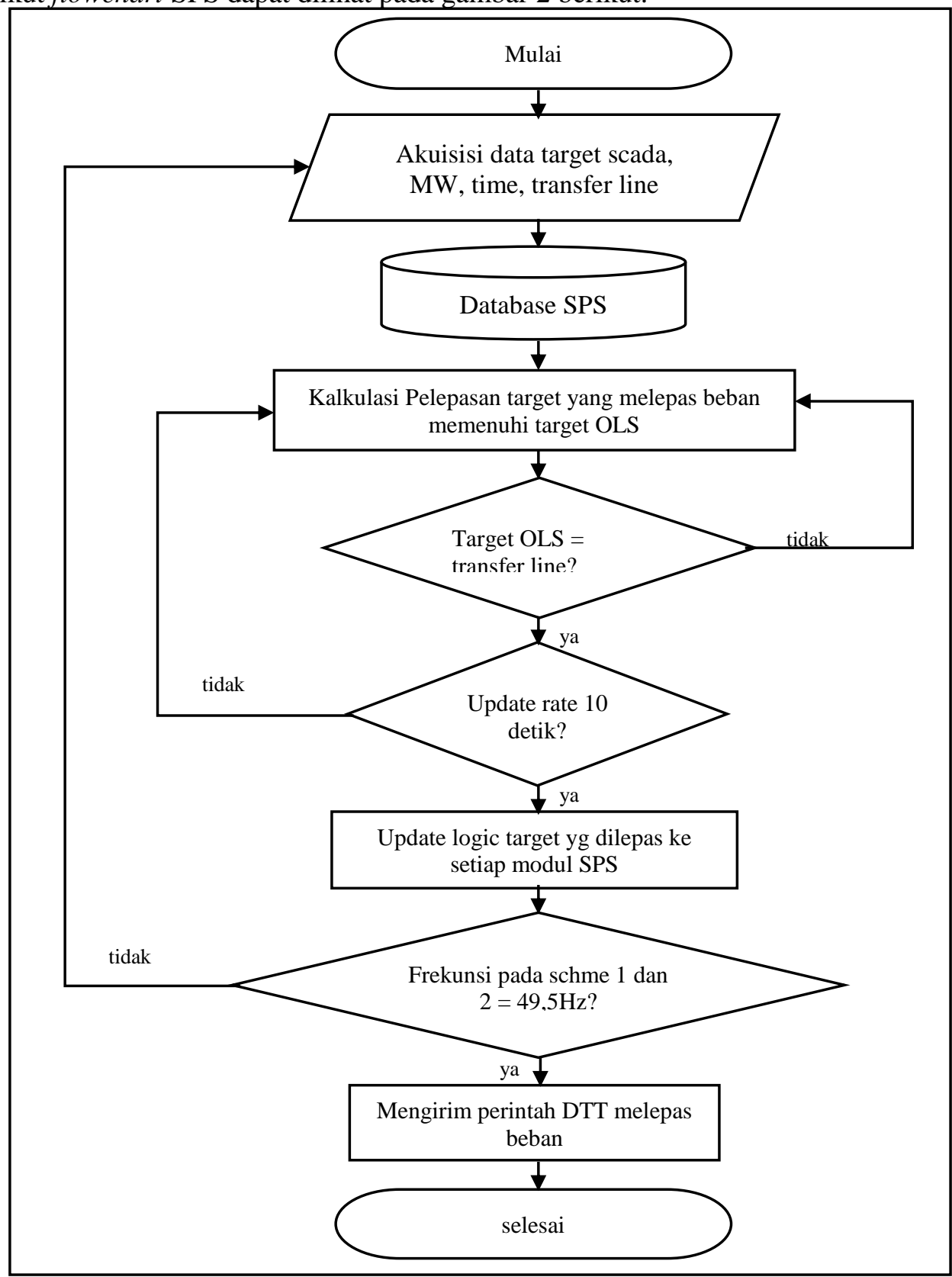

Gambar 2. Flowchart special protection scheme

Adapun langkah-langkah dalam membangun SPS ini sebagai berikut:

A. Buka microsoft office excel lalu beri nama SPS dengan format (.xlsm) buat 5 sheet dengan bagian dapat dilihat pada gambar 3 berikut:

\begin{tabular}{|l|l|l|l|l|}
\hline SPS1 & SPS2 & New_Data1 & New_Data2 & Oracle \\
\hline
\end{tabular}

Gambar 3. Bagian sheet SPS

Sheet Oracle merupakan sheet yang digunakan untuk meng-import data TA dari database Oracle ke microsoft office excel, sheet New_Data1 merupakan sheet yang digunakan untuk 
skema Barikin - Tanjung dan sheet New_Data2 untuk skema Barikin - Cempaka, Sheet SPS1 dan sheet SPS2 merupakan sheet yang akan diisi dengan query macro untuk mengelola SPS.

B. Import data TA dari database Oracle dapat dilihat pada Tabel 1 berikut:

Tabel 1. Import data TA dari database Oracle ke Microsoft Office Excel

\begin{tabular}{|c|c|c|c|c|c|c|c|c|}
\hline B1 & B2 & B3 & ELEMENTS & DATUM & WERT1 & $\begin{array}{c}\text { KENN } \\
\text { FELD1 }\end{array}$ & ID & $\begin{array}{c}\text { DATUM_ } \\
\text { CAPTURE }\end{array}$ \\
\hline BTLCN & 20 & INC52-1 & Q & 43482.425 & -2.84 & act & 967 & 43482.42488 \\
\hline SELAT & 150 & TRF52-2 & P & 43482.425 & 6.57 & act & 973 & 43482.42488 \\
\hline AMTAI & 20 & AM-6 & P & 43482.425 & 1.06 & act & 1004 & 43482.42488 \\
\hline PMNOR & 70 & CMPKA-2 & P & 43482.425 & 5.18 & act & 771 & 43482.42488 \\
\hline CMPKA & 70 & TRF52-7 & P & 43482.425 & 0 & exi & 825041 & 43482.42488 \\
\hline TNJNG & 150 & KUARO-1B & P & 43482.425 & -30.44 & act & 825061 & 43482.42488 \\
\hline TNJNG & 150 & KUARO-1B & Q & 43482.425 & 0.49 & act & 825062 & 43482.42488 \\
\hline TNJNG & 150 & KUARO-1B & V & 43482.425 & 149.22 & act & 825063 & 43482.42488 \\
\hline
\end{tabular}

Tabel 1 merupakan tabel dengan data B1, B2, B3 ELEMENT, DATUM, WERT1, KENFELD1, ID dan DATUM_CAPTURE yang dinamakan TA. Pada TA yang di-import memiliki 824989 data yang dikelola SCADA namun kita hanya akan melakukan perlindungan sistem sesuai dengan skema Barikin arah Tanjung dan Barikin arah Cempaka.

C. Filter data TA ke sheet New_Data1 dapat dilihat pada tabel 2 berikut:

Tabel 2 Filter data TA ke sheet New_Data1

\begin{tabular}{|c|c|c|c|c|c|c|c|c|}
\hline GI & ID & Nama & Prioritas & B1 & B2 & B3 & $\begin{array}{c}\text { Data } \\
\text { real time }\end{array}$ & $\begin{array}{c}\text { Time } \\
\text { taken }\end{array}$ \\
\hline \multirow{3}{*}{$\begin{array}{l}\text { PALANG } \\
\text { KARAYA }\end{array}$} & 1 & $\begin{array}{c}\text { LINE } 1 \text { PALANGKA } \\
\text { - KASONGAN }\end{array}$ & 1 & PLKRY & 150 & KSGAN-1 & 20.87 & $\begin{array}{c}1 / 17 / 2019 \\
10-11 \\
\end{array}$ \\
\hline & 2 & $\begin{array}{c}\text { LINE } 2 \text { PALANGKA } \\
\text { - KASONGAN }\end{array}$ & 1 & PLKRY & 150 & KSGAN-2 & 20.95 & $\begin{array}{c}1 / 17 / 2019 \\
10-11\end{array}$ \\
\hline & 3 & Tr.2 PLK (30 MVA) & 1 & PLKRY & 150 & TRF52-2 & 8.94 & $\begin{array}{c}1 / 17 / 2019 \\
10-11 \\
\end{array}$ \\
\hline $\begin{array}{l}\text { PULANG } \\
\text { PISAU }\end{array}$ & 4 & $\begin{array}{c}\text { Tr.1 PULPIS (10 } \\
\text { MVA) }\end{array}$ & 1 & PPSAU & 150 & TRF52-1 & 5.22 & $\begin{array}{c}1 / 17 / 2019 \\
10-11 \\
\end{array}$ \\
\hline MINTIN & 5 & $\begin{array}{c}\text { Tr.1 MINTIN (10 } \\
\text { MVA) }\end{array}$ & 1 & MNTIN & 150 & TRF52-1 & 0.00 & $\begin{array}{c}1 / 17 / 2019 \\
10-11 \\
\end{array}$ \\
\hline SELAT & 6 & Tr.2 SLT (30 MVA) & 1 & SELAT & 150 & TRF52-2 & 6.57 & $\begin{array}{c}1 / 17 / 2019 \\
10-11\end{array}$ \\
\hline SEBAR & 7 & $\begin{array}{c}\text { Tr.2 SEBAR (20 } \\
\text { MVA) }\end{array}$ & 1 & SEBAR & 150 & TRF52-2 & 2.74 & $\begin{array}{c}1 / 17 / 2019 \\
10-11 \\
\end{array}$ \\
\hline $\begin{array}{l}\text { KAYU } \\
\text { TANGI }\end{array}$ & 8 & $\begin{array}{l}\text { Tr.1 KAYU TANGI } \\
\text { (30 MVA) }\end{array}$ & 1 & KYTNG & 20 & INC52-1 & 14.52 & $\begin{array}{c}1 / 17 / 2019 \\
10-11 \\
\end{array}$ \\
\hline \multirow{2}{*}{$\begin{array}{l}\text { TRISAKTI } \\
150\end{array}$} & 9 & $\begin{array}{c}\text { Tr.5 } 150 \mathrm{KV}(60 \\
\text { MVA) }\end{array}$ & 1 & TRST5 & 150 & TRF52-5 & 0.00 & $\begin{array}{c}1 / 17 / 2019 \\
10-11\end{array}$ \\
\hline & 10 & $\begin{array}{c}\text { Tr.6 } 150 \text { KV (60 } \\
\text { MVA) }\end{array}$ & 1 & TRST5 & 150 & TRF52-6 & 28.51 & $\begin{array}{c}1 / 17 / 2019 \\
10-11 \\
\end{array}$ \\
\hline \multirow{2}{*}{ ULIN } & 11 & Tr.1 ULIN (30 MVA) & 1 & ULIN & 70 & TRF42-1 & 9.91 & $\begin{array}{c}1 / 17 / 2019 \\
10-11 \\
\end{array}$ \\
\hline & 12 & Tr.6 ULIN (30 MVA) & 1 & TR6UL & 20 & INC42-6 & 18.42 & $\begin{array}{c}1 / 17 / 2019 \\
10-11 \\
\end{array}$ \\
\hline MANTUIL & 13 & $\begin{array}{c}\text { Tr.1 MANTUIL (30 } \\
\text { MVA) }\end{array}$ & 1 & MTUIL & 150 & TRF52-1 & 18.34 & $\begin{array}{c}1 / 17 / 2019 \\
10-11 \\
\end{array}$ \\
\hline \multirow{2}{*}{ CEMPAKA } & 14 & $\begin{array}{c}\text { Tr.5 CEMPAKA (30 } \\
\text { MVA) }\end{array}$ & 1 & CMPKA & 150 & TRF52-5 & 4.50 & $\begin{array}{c}1 / 17 / 2019 \\
10-11 \\
\end{array}$ \\
\hline & 15 & $\begin{array}{c}\text { Tr.7 CEMPAKA (60 } \\
\text { MVA) }\end{array}$ & 1 & CMPKA & 150 & TRF52-7b & 10.25 & $\begin{array}{c}1 / 17 / 2019 \\
10-11\end{array}$ \\
\hline $\begin{array}{l}\text { PELAI } \\
\text { HARI }\end{array}$ & 16 & Tr.2 PLH (30 MVA) & 1 & $\begin{array}{l}\text { NEW } \\
\text { PLHRI }\end{array}$ & 150 & TRF52-2 & 0.00 & $\begin{array}{c}1 / 17 / 2019 \\
10-11\end{array}$ \\
\hline
\end{tabular}


Dalam skema Barikin - Tanjung ini kita memiliki 24 target beban yang akan dilepas dengan tabel heading yang diambil dari sheet Oracle hanya B1, B2, B3 data real time (Mw) dan DATUM atau Time Taken.

Filter data TA ke sheet New_Data2 dapat dilihat pada Tabel 3.

Tabel 3 Filter data TA ke sheet New_Data2

\begin{tabular}{|c|c|c|c|c|c|c|c|c|}
\hline GI & ID & Nama & Prioritas & B1 & B2 & $\mathbf{B 3}$ & $\begin{array}{c}\text { Data real } \\
\text { time }\end{array}$ & $\begin{array}{l}\text { Time } \\
\text { taken }\end{array}$ \\
\hline \multirow{3}{*}{ PALANGKA } & 1 & $\begin{array}{l}\text { LINE } 1 \text { PALANGKA } \\
\text { - KASONGAN }\end{array}$ & 1 & PLKRY & 150 & KSGAN-1 & 20.87 & $\begin{array}{c}1 / 17 / 2019 \\
10-11 \\
\end{array}$ \\
\hline & 2 & $\begin{array}{l}\text { LINE } 2 \text { PALANGKA } \\
\text { - KASONGAN }\end{array}$ & 1 & PLKRY & 150 & KSGAN-2 & 20.95 & $\begin{array}{c}1 / 17 / 2019 \\
10-11 \\
\end{array}$ \\
\hline & 3 & Tr.2 PLK (30 MVA) & 1 & PLKRY & 150 & TRF52-2 & 8.94 & $\begin{array}{c}1 / 17 / 2019 \\
10-11 \\
\end{array}$ \\
\hline $\begin{array}{l}\text { PULANG } \\
\text { PISAU }\end{array}$ & 4 & $\begin{array}{l}\text { Tr.1 PULPIS (10 } \\
\text { MVA) }\end{array}$ & 1 & PPSAU & 150 & TRF52-1 & 5.22 & $\begin{array}{c}1 / 17 / 2019 \\
10-11 \\
\end{array}$ \\
\hline MINTIN & 5 & $\begin{array}{l}\text { Tr.1 MINTIN (10 } \\
\text { MVA) }\end{array}$ & 1 & MNTIN & 150 & TRF52-1 & 0.00 & $\begin{array}{c}1 / 17 / 2019 \\
10-11 \\
\end{array}$ \\
\hline SELAT & 6 & Tr.2 SLT (30 MVA) & 1 & SELAT & 150 & TRF52-1 & 7.22 & $\begin{array}{c}1 / 17 / 2019 \\
10-11 \\
\end{array}$ \\
\hline SEBAR & 7 & $\begin{array}{c}\text { Tr.2 SEBAR (20 } \\
\text { MVA) }\end{array}$ & 1 & SEBAR & 150 & TRF52-2 & 2.74 & $\begin{array}{c}1 / 17 / 2019 \\
10-11 \\
\end{array}$ \\
\hline $\begin{array}{l}\text { KAYUTANG } \\
\text { I }\end{array}$ & 8 & $\begin{array}{l}\text { Tr.1 KAYU TANGI } \\
\text { (30 MVA) }\end{array}$ & 1 & KYTNG & 20 & INC52-1 & 14.52 & $\begin{array}{c}1 / 17 / 2019 \\
10-11\end{array}$ \\
\hline $\begin{array}{l}\text { TRISAKTI } \\
150\end{array}$ & 9 & $\begin{array}{c}\text { Tr.6 } 150 \mathrm{KV}(60 \\
\text { MVA) }\end{array}$ & 1 & TRST5 & 150 & TRF52-6 & 28.51 & $\begin{array}{c}1 / 17 / 2019 \\
10-11\end{array}$ \\
\hline MANTUIL & 10 & $\begin{array}{c}\text { Tr.1 MANTUIL (30 } \\
\text { MVA) }\end{array}$ & 1 & MTUIL & 150 & TRF52-1 & 18.34 & $\begin{array}{c}1 / 17 / 2019 \\
10-11\end{array}$ \\
\hline PELAIHARI & 11 & Tr.2 PLH (30 MVA) & 1 & $\begin{array}{c}\text { NEWPL } \\
\text { HRI }\end{array}$ & 150 & TRF52-2 & 0.00 & $\begin{array}{c}1 / 17 / 2019 \\
10-11 \\
\end{array}$ \\
\hline
\end{tabular}

Dalam skema Barikin - Tanjung ini kita memiliki 15 target beban yang akan dilepas dengan tabel heading yang diambil dari sheet Oracle hanya B1, B2, B3 ELEMENT (P), WERT atau MW dan DATUM atau Time Taken. Dari kedua sheet New_Data1 dan New_Data2 akan kita buat sheet SPS1 dan sheet SPS2 untuk mengelola MW. MW adalah singkatan dari Mega Watt atau beban yang disalurkan dari line transmisi ke pelanggan. MW ini yang akan di kelola dalam pelepasan beban secara dinamis.

D. Sheet SPS1 untuk mengelola skema Barikin - Tanjung dapat dilihat pada Gambar 4.

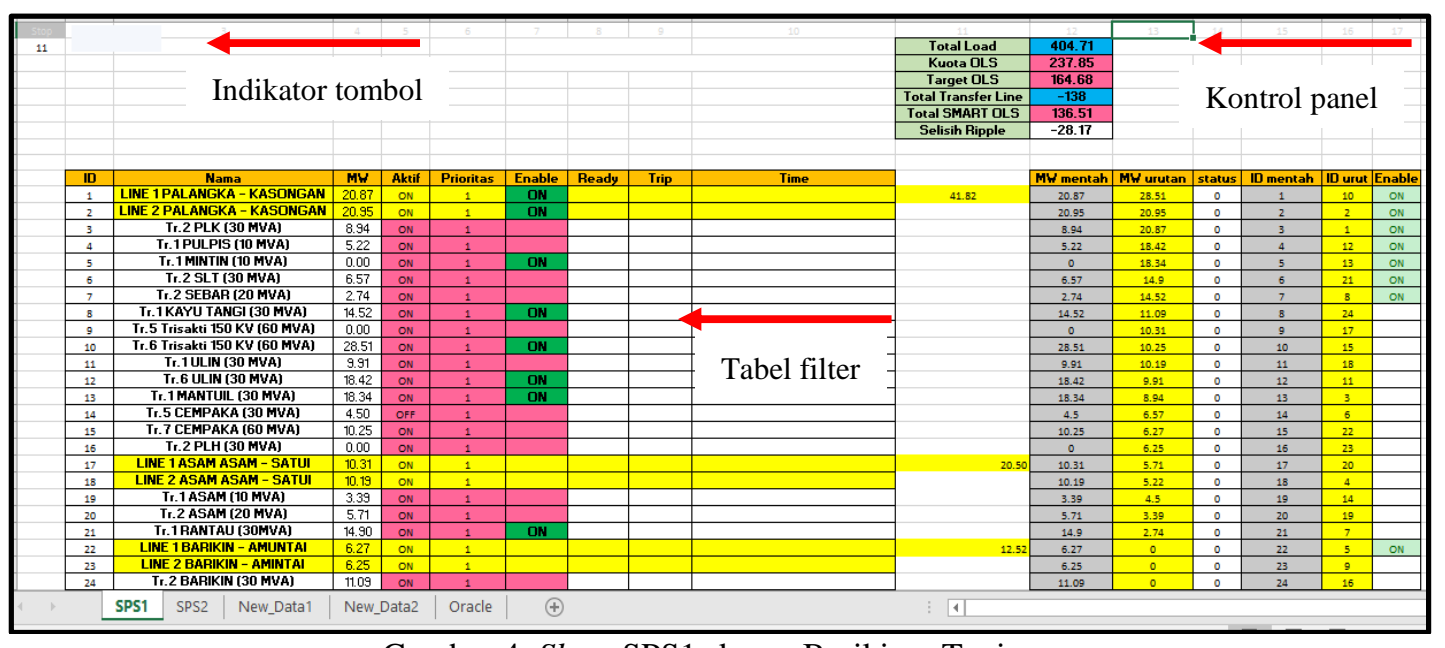

Gambar 4. Sheet SPS1 skema Barikin - Tanjung 
Pada gambar 4 terdapat indikator tombol run dan stop, tabel filter, tabel filter enable dan kontrol panel skema Barikin - Tanjung. Indikator tombol run dan stop merupakan tombol menyalakan dan menghentikan program SPS, tabel filter merupakan filter MW dari sheet New_Data1 jadi yang diperlukan pada sheet SPS1 ini adalah Nama line transmisi dan MW saja. Tabel filter enable merupakan tabel yang mengurutkan beban dari terbesar hingga terkecil dapat diperhatikan pada kolom yang berwarna kuning serta status enable on akan berwarna kolom hijau. Target yang memiliki nilai enable on merupakan total target yang memiliki nilai beban yang sama dengan transfer line. Nilai enable target on ini akan diambil oleh mini-pc (rapberry) dan mini-pc akan memberikan feedback sinyak ready on. Pada saat target bernilai enable dan ready on dan terjadi gangguan SPS akan melepas beban sesuai dengan target beban yang mengikuti nilai transfer line, pelepasan beban terjadi secara dinamis dan tidak memerlukan waktu pemulihan yang lama serta tidak menyebabkan gangguan yang dapat membuat black out pada sistem kelistrikan. Catatan: SPS1 sama dengan SPS2 hanya saja perbedaan jumlah target.

E. Source code SPS1 untuk mengurutkan data target dan memberikan nilai enable on pada saat target memiliki status aktif on dan memenuhi syarat kuota OLS dapat dilihat pada Gambar 5.

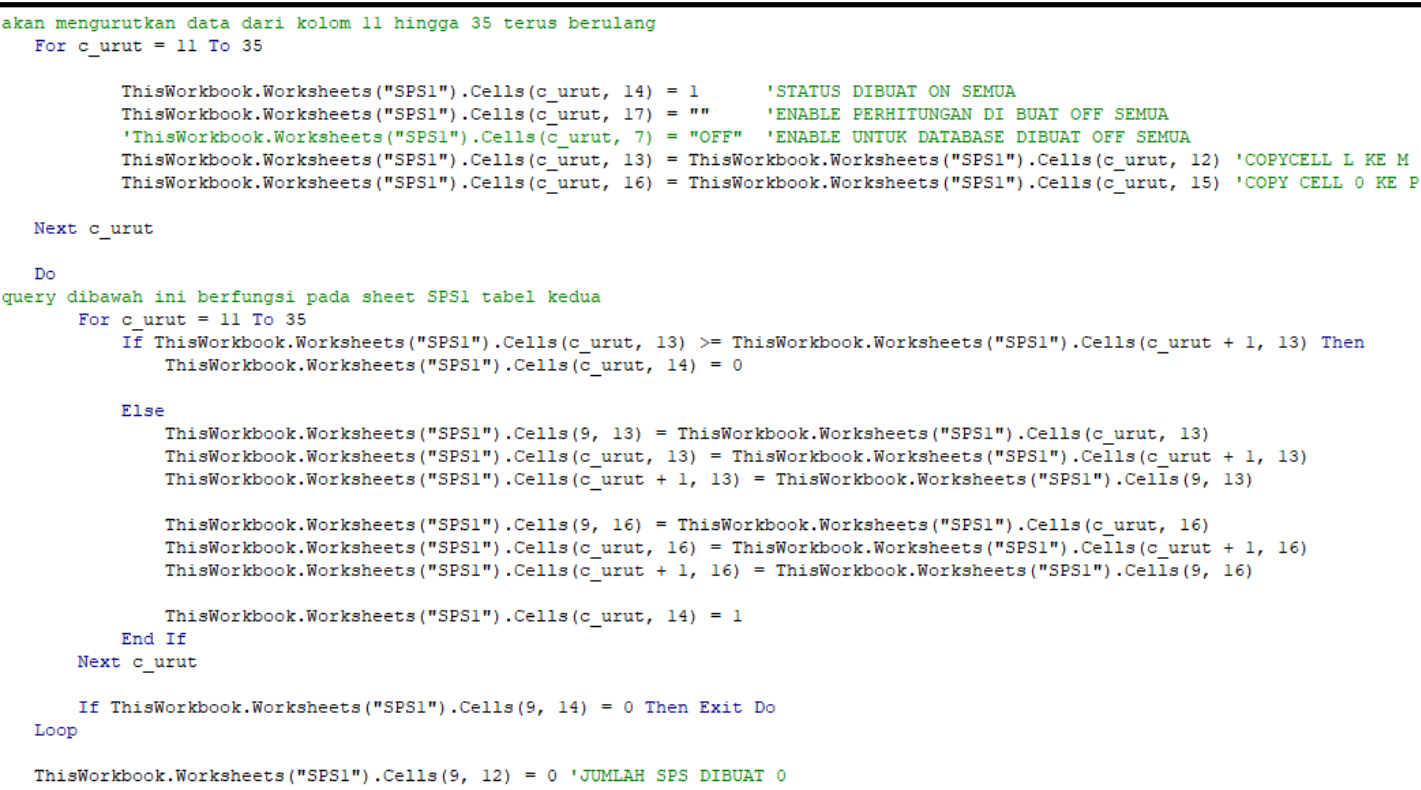

Gambar 5. Mengurutkan data target

Pada Gambar 5 merupakan potongan source code untuk mengurutkan data target. Pada perulangan target beban dihitung apakah total beban mendekati atau setara dengan nilai transfer line. Jika target termasuk dalam total SPS maka akan di cek statusnya. Kode program cek aktif target dapat dilihat pada Gambar 6 berikut: 


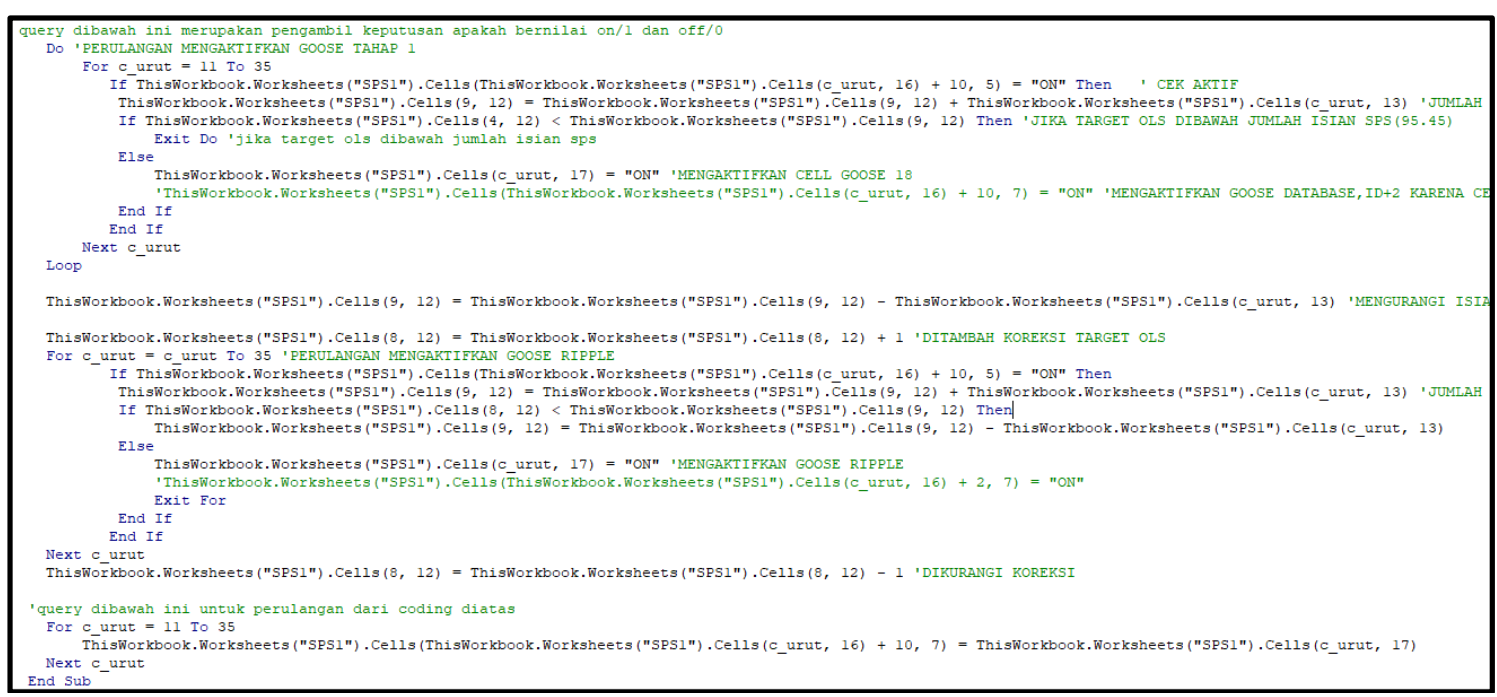

Gambar 6. Mengecek status aktif

Gambar 6 menunjukkan pengecekkan target, jika status aktif maka target bernilai enable ON. Status target aktif ini berfungsi sebagai tanda saat suatu wilayah tidak dimasukkan dalam melepas beban maka target akan dibuat status off. Data TA setiap skema disimpan pada database MySQL dan dimonitoring pada halaman browser dengan tool Node-RED.

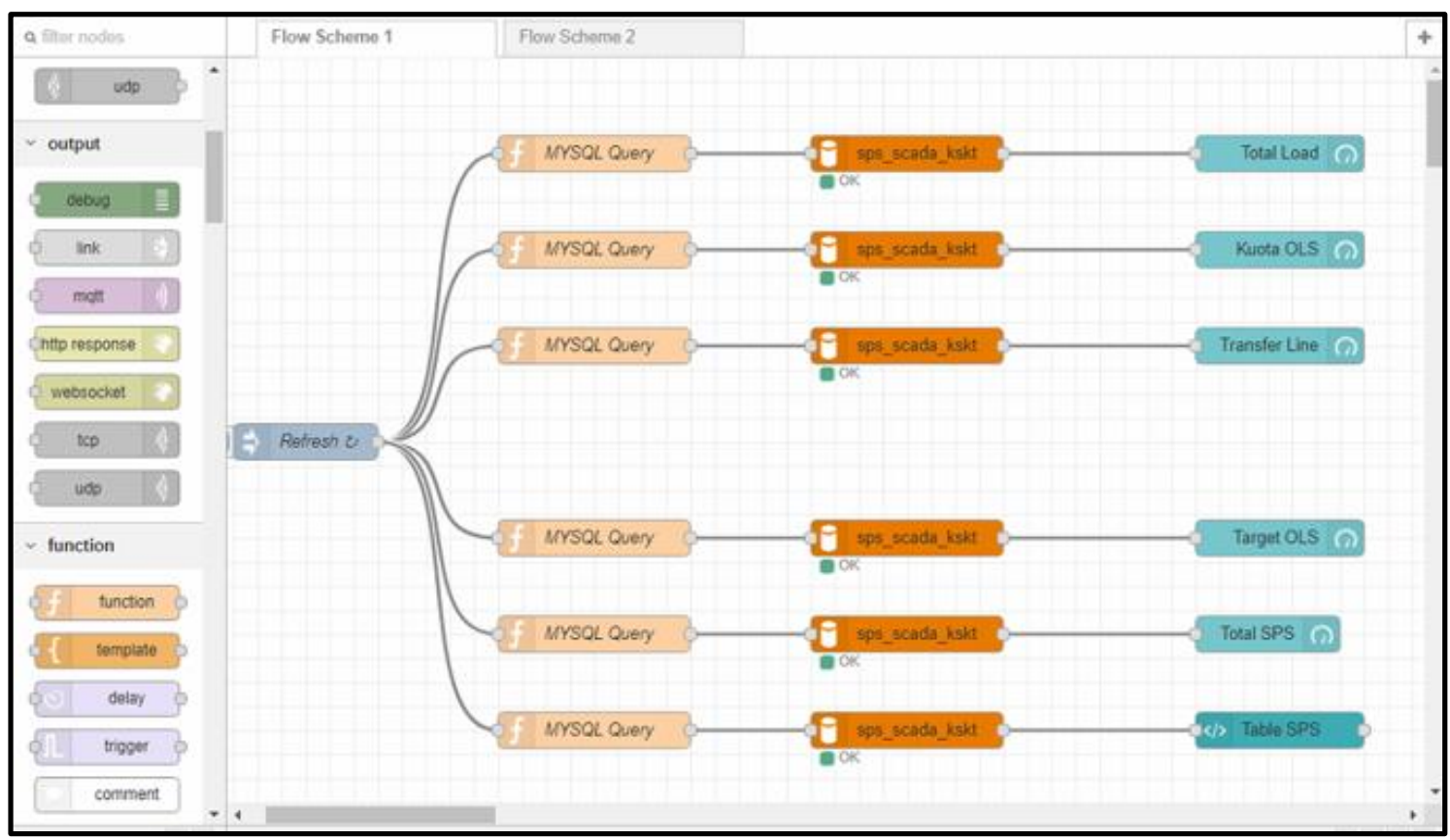

Gambar 7. Flow data SPS

Gambar 7 merupakan flow data SPS yang ditampilkan pada halaman browser. Halaman interface SPS dapat dilihat pada Gambar 8 berikut: 


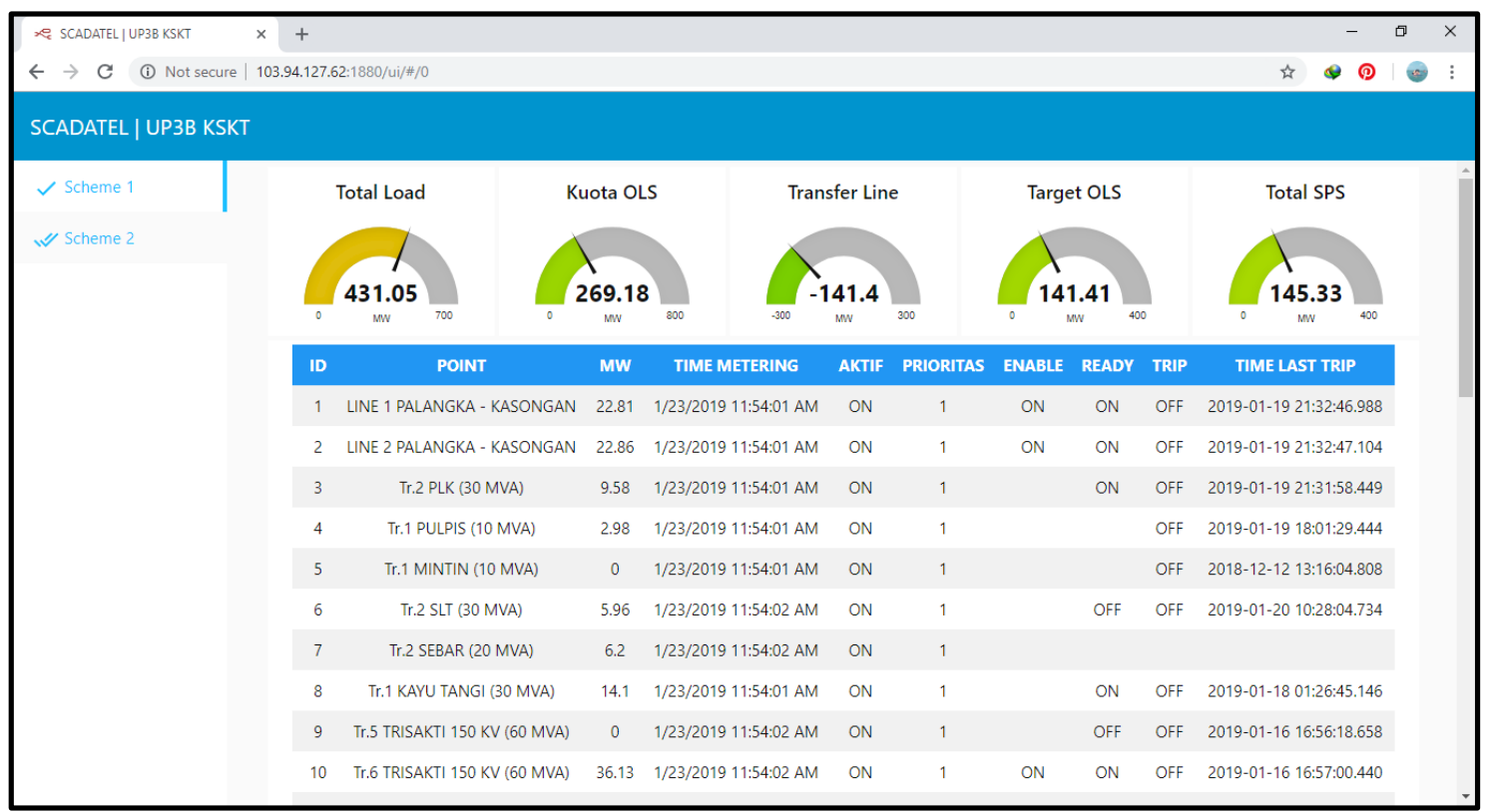

Gambar 8 Tampilan antarmuka SPS1

Gambar 8 merupakan implementasi interface dari SPS1. Terdapat beberapa kontrol panel yang menunjukkan keadaan beban saat itu dan dapat dilihat secara real-time maneuver dari setiap target. Target yang siap melepas beban hingga pelepasan beban terjadi secara dinamis. Keterangan dari kontrol panel pada gambar 8 tersebut yaitu:

\section{1) Total Load}

Total load merupakan konsumsi beban kelistrikan yang digunakan masyarakat seKalimantan Selatan dan Kalimantan Tengah.

\section{2) Kuota OLS}

Kuota OLS (on load shedding) merupakan jumlah total frekuensi MW pada sheet SPS1 sebanyak 24 target (kolom POINT) dan SPS2 sebanyak 15 target.

\section{3) Transfer Line}

Transfer line merupakan keadaan total beban yang digunakan pada line transmisi Barikin Tanjung untuk SPS1 dan Barikin - Cempaka untuk SPS2. Transfer line ini yang akan dilindungi pada saat terjadi beban berlebih dan akan digantikan oleh beban dari Total SPS yang berasal dari perhitungan dari target siap melepas beban (OLS).

4) Target OLS

Target OLS (on load shedding) merupakan beban yang disiapkan apabila transfer line pada masing-masing scheme terjadi gangguan. Beban OLS ini berasal dari perhitungan macro VBA yang telah memenuhi syarat untuk melepas beban.

5) Total SPS

Total SPS (special protection scheme) merupakan hasil perhitungan dari macro VBA dengan metode descending dimana target akan dikalkulasi dari beban tertinggi hingga paling rendah dan benilai enable dan ready $=$ ON dan total beban dari target yang apabila dijumlah akan mendekati atau melebihi total target OLS yang nantinya akan menyelematkan transfer line pada saat terjadi gangguan. 


\section{KESIMPULAN}

Berdasarkan pembahasan dari point 4, dapat diperoleh kesimpulan bahwa Sistem Proteksi Pelepasan Beban dengan Metode Descending berbasis Macro VBA pada PT. PLN (Persero) UP3B Sistem Kalimantan Selatan dan Kalimantan Tengah dibangun dengan menggunakan aplikasi macro VBA dapat melindungi sistem ketenaga listrikan pada saat terjadi gangguan beban berlebih (over load).

Perlindungan SPS melepas beban yang besar dan ditentukan oleh kalkukasi dari macro VBA, beban yang besar dimasukkan kedalam target OLS (beban yang siap dilepas), target OLS selalu menyesuaikan perubahan beban yang digunakan transfer line sehingga pada saat nilai beban transfer line mengalami gangguan beban digantikan dengan total sps yang berasal dari kuota OLS (beban skema). Pada saat gangguan terjadi sistem SPS mengirim perintah DTT untuk melepas beban dengan kolom status TRIP menjadi ON, maka data dicatat pada kolom time last trip lalu Raspberry bekerja untuk memutus beban pada target point skema.

Sistem Special Protection Scheme telah mampu memenuhi target pembuangan beban secara dinamis dengan memperhitungkan beban yang siap dibuang sesuai dengan metode descending. SPS merupakan perlindungan terhadap sistem kelistrikan yang berada di wilayah Kalimantan Selatan dan Kalimantan Tengah yang bekerja secara dinamis dengan melepas beban berdasarkan kondisi beban secara real-time sesuai skema yang telah ditentukan. Hal itu bertujuan untuk menghindari gangguan meluas yang dapat menyebabkan black out pada sistem kelistrikan.

\section{DAFTAR PUSTAKA}

Hongsheng, L. (2010). Programming VBA Macro with the Recording Tool of Excel. In 2010 International Conference on Computer and Communication Technologies in Agriculture Engineering (pp. 53-56).

Mohammed, A. S., Amrahov, Ş. E., \& Çelebi, F. V. (2017). Bidirectional conditional insertion sort algorithm; An efficient progress on the classical insertion sort. Future Generation Computer Systems, 71, 102-112.

Mulyono, S., Qomaruddin, M., \& Anwar, M. S. (2018). Penggunaan Node-RED pada Sistem Monitoring dan Kontrol Green House berbasis Protokol MQTT. TRANSISTOR Elektro Dan Informatika, 3(1), 31-44.

Shan, B., Zhao, D., Zhang, X., Guan, F., \& Liu, Z. (2009). Research on Relay Protection Setting Expert System for Main Equipment in Power Plant. In 2009 International Conference on Sustainable Power Generation and Supply (pp. 1-4). IEEE. 